\title{
ARTIFICIAL RELEASE OF AVALANGHES BY EXPLOSIVES
}

\author{
By H. Gubler \\ (Eidgenössisches Institut für Schnee- und Lawinenforschung, 726o Weissfluhjoch/Davos, \\ Switzerland)
}

\begin{abstract}
The method of the artificial release of slab avalanches by explosives is investigated. The effect of a detonation on a seasonal snow cover is measured and discussed. The attenuation of the resulting stress waves as a function of the type of explosive used, the position of the charge relative to the snow surface, the charge mass, the snow-stratification profile, and the type of ground are determined in field experiments. The effective ranges of shots in potential fracture zones are estimated.

RÉsumé. Déclenchement artificiel d'avalanches de neige par explosifs. La méthode du déclenchement artificiel d'avalanches de plaques de neige par explosifs est examinée. Les effets d'une détonation sur une couche de neige saisonale sont mesurées et discutées. On détermine par des essais en champ libre l'atténuation des ondes de pression résultantes en fonction de l'explosif employé, de la position de la charge relative à la surface de la neige, du poids de la charge, du profil stratigraphique de la couche de neige et de la constitution du sol. La portée de charges explosives dans des zones de décrochement potentielles est jugée.

Zusammenfassung. Künstliche Auslösung von Lawinen durch Sprengungen. Die Methode der künstlichen Auslösung von Schneebrett-Lawinen durch Sprengungen wird untersucht. Die Wirkung einer Detonation auf eine Saisonschneedecke wird gemessen und diskutiert. Die Attenuation der resultierenden Druckwellen als Funktion des verwendeten Sprengstoffes, der Ladungsposition relativ zur Schneeoberfläche, des Ladungsgewichtes, des Schneedeckenprofils sowie der Art des Untergrundes werden in Feldexperimenten bestimmt. Der Wirkungsbereich von Sprengladungen in möglichen Anrissgebieten wird abgeschätzt.
\end{abstract}

\section{INTRODUCTION}

Because of the rapid development of large ski areas at high altitude in the Alps, immense problems have arisen concerning the protection of ski runs from avalanches. Explosives have long been used for the controlled release of avalanches. Different methods of charge emplacement are in use:

I. Hand delivery, by which solid charges are either placed on the snow (in fresh snow unfortunately they may sink below the surface) or by fixing them to piles about $\mathrm{I}-2 \mathrm{~m}$ above the snow surface.

2. Projectile delivery, by which charges are fired into the target zone by guns and ignition may occur near or below the snow surface depending on the detonator used.

3. Charges are brought to the target zone by special small cable cars and are generally fired above the snow surface.

Different explosives are in use with a wide range of detonation velocities. Also, sizes and shapes of the charges differ widely. In Switzerland, $(\mathrm{I}-\mathrm{I} .5) \times \mathrm{IO}^{4}$ charges are ignited every year with a mean efficiency (avalanches released) of $20-30 \%$. From this fact arises the question concerning the interpretation of unsuccessful shots. Was the charge emplacement not optimal or was the slope really stable? To answer this question, the very limited quantitative information has to be improved.

Only a few of the investigations have dealt with the effect of explosives on the seasonal snow cover (LaChapelle, I956; Mellor, 1973). There are other reports describing the effect of explosives on an Arctic snow cover. Unfortunately most of the investigations are limited to the crater zone. For the controlled release of avalanches by explosives we need more information on the effect of pressure waves in a potential fracture zone of a slab avalanche outside the crater. A research project designed to seek alternative methods of avalanche control was started 2 years ago by LaChapelle and others (1975). 


\section{Aim of the investigations}

The effect of explosives on the seasonal snow cover will be investigated quantitatively. The mechanism by which explosions release avalanches has to be clarified. The tests should result in quantitative laws governing the propagation of stress waves in, above and at the base of the snow cover as a function of charge type, size, shape, charge position relative to the snow surface and the snow stratification. To answer the main question of the remaining risks after unsuccessful shots, the stability development after the detonation and the minimal effective range of a shot as a function of slope stability have to be evaluated.

\section{General plan of the tests}

I. Investigation of the propagation of stress waves originating from detonations in, above, and below the seasonal snow cover.

2. Relative effects of different explosives, charge shapes and sizes.

3. Effect of stress waves on the snow structure.

4. Measurement and estimation of natural and pressure-wave induced stability variations in potential fracture zones of slab avalanches.

5. Verification of the conclusions from the investigations on avalanche slopes.

QUALITATIVE DESCRIPTION OF ORIGIN AND PROPAGATION OF SHOGK AND STRESS WAVES IN AND ABOVE THE SNOW COVER

The development of stress waves in and above the snow cover depends mainly on the position of the detonating charge relative to the snow surface. The coupling between an explosive charge and snow is poor, and the impedance matching is far from ideal. Porous materials such as snow are very effective energy-absorbing media. The attenuation of stress waves propagating from a blast in the snow cover is very high. Most of the energy is absorbed

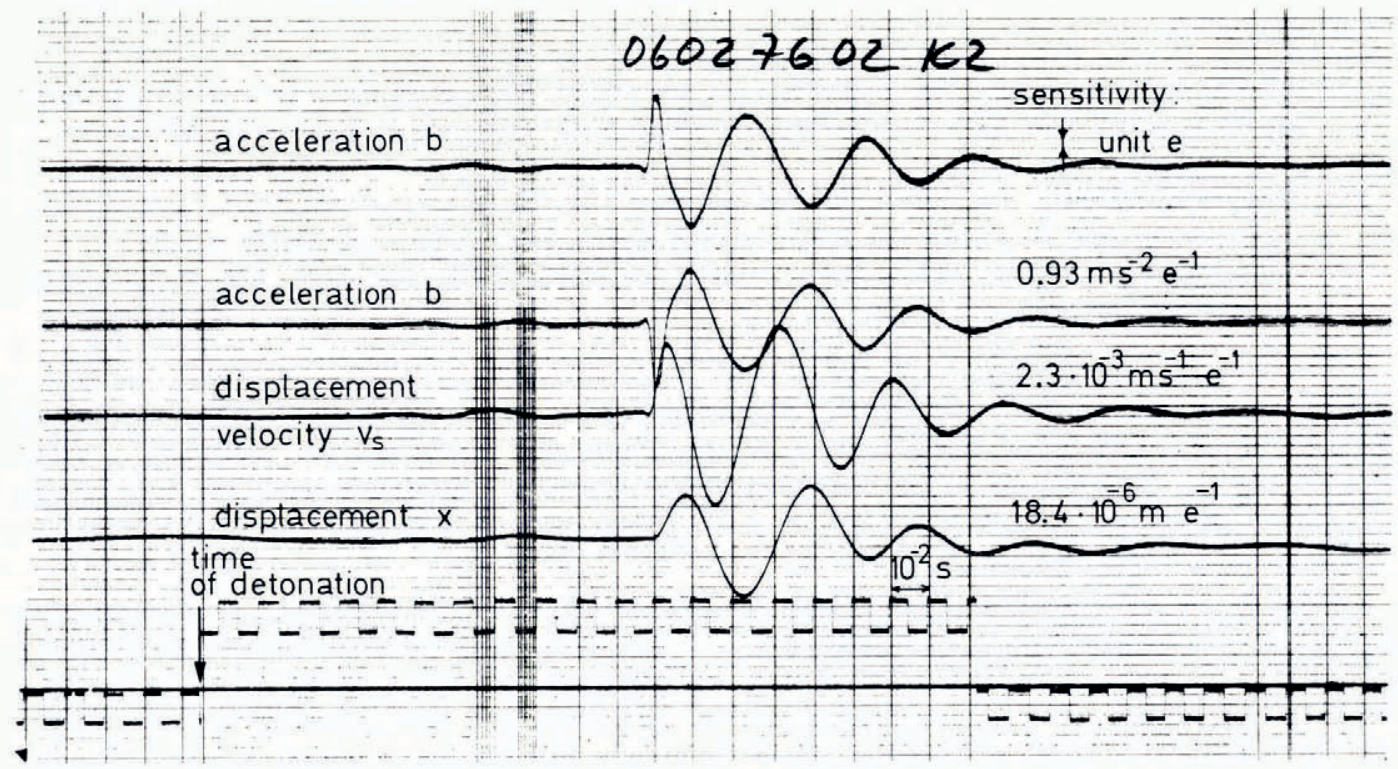

Fig. I. Example of an acceleration signal and its integrations. $I \mathrm{~kg}$ charge fired $\mathrm{I} \mathrm{m}$ above the snow surface. Distance to ground zero $40 \mathrm{~m}$, depth of transducer $0.6 \mathrm{~m}$. 
in the crater zone. A charge fired near or above the snow surface causes a high-pressure shock wave propagating over the snow surface. For the charge masses (several kilograms) generally used to release avalanches, the shock waves develop almost immediately into N-shaped pressure waves (N-wave) propagating with the velocity of sound over the snow surface. This $\mathrm{N}$-wave acts through the pore system of the snow resting on the ice skeleton and excites stronglydamped oscillations in the snow cover. Shots fired below the surface of the dry snow cover (snow depth not exceeding $2 \mathrm{~m}$ ) also produce $\mathrm{N}$-waves propagating over the snow surface but with peak pressures reduced by $\mathrm{I}-2$ orders of magnitude. For distances of $s>\mathrm{I} 0 \mathrm{~m}$, the resulting oscillation amplitudes of the snow cover are decreased by about $\mathbf{I}-2$ orders of magnitude compared with the values for shots above the snow surface. But the maximum amplitude is always reached after the arrival of the $\mathrm{N}$-wave. The significant difference between the propagation velocities of the $\mathrm{N}$-wave (velocity of sound) and the stress wave in snow $\left(v_{0 \mathrm{~s}}=500-\mathrm{I} 000 \mathrm{~m} / \mathrm{s}\right)$ allows one to distinguish between the two energy transfers. The main components of the oscillations induced by $\mathrm{N}$-waves are vertical, whereas the main components of the direct stress waves are radial and parallel to the snow surface. The acceleration of snow structure at a distance $s$ of about $10 \mathrm{~m}$ from ground zero mainly consists of an early-arrival direct component, mainly radially oscillating (with a small amplitude), followed by the sharp signal of the induced $\mathrm{N}$-wave and the resulting oscillations of the snow cover (Fig. I).

\section{Parameters to be measured}

The general aim of blasting is to diminish stability on an inclined snow cover by increasing stress, by decreasing strength, or by a combination of the two. Knowing the stability and strength of the snow cover, we are able to estimate the additional stresses which have to be created by the stress waves. For various reasons, a direct measurement of the dynamic stresses in the ice skeleton of the snow is almost impossible. It is important to remember that the snow stresses in a simple pressure measurement are masked by the air pressure wave (N-wave) penetrating from the snow surface into the snow cover. Only a simultaneous measurement of the total snow stress and the void pressure would produce explainable results. But the freezing of matched pressure transducers into the snow structure without destroying the ice skeleton in a field experiment proved to be almost impossible.

A less complicated method is by measuring the absolute snow acceleration $b$. Simple analogue integrations of the acceleration signals give as a result the displacement velocity $v_{\mathrm{S}}$ and the displacement $x$ of the snow. The recording of the arrival times of the direct waves (propagated in the snow cover) and of the $\mathrm{N}$-waves as a function of the distance $s$ to ground zero allow one to calculate the corresponding propagation velocities $v_{01}$ and $v_{\mathrm{os}}$. Knowing $v_{\mathrm{os}}$ and $v_{\mathrm{s}}$, the strain $\epsilon$, the corresponding strain-rate dependent Young's modulus $E(\dot{\epsilon})$ and the additional snow stress $\sigma_{\mathrm{s}}$ may be estimated:

$$
\begin{aligned}
\epsilon & =v_{\mathrm{s}} / v_{0 \mathrm{~s}} \text { for dimensions negligible compared with wavelength } \lambda . \\
E & \approx \rho v_{\mathrm{os}}^{2}, \rho: \text { mean density of the snow cover. } \\
\sigma_{\mathrm{S}} & \approx \rho v_{\mathrm{s}} v_{0 \mathrm{~s}} .
\end{aligned}
$$

Using simple models for the structural elements conducting the stresses in the ice skeleton of the snow, one may also estimate the maximum stresses in the bonding between the ice grains. Comparing the deformation power of stressed bonds with the experimentally determined power to fracture a single bond, the necessary strain-rate $\dot{\epsilon}$ to fracture a specific snow cover can also be estimated (Gubler, I $976[\mathrm{~b}]$ ). To test the effect of the additional stress on the bonds, the acoustic emissions originating from breaking chains of ice grains are measured. 


\section{EXPERIMENTAL SET-UP}

The principal electronic set-up is given in Figure 2 and the technical data of the transducers are given in Table I. The whole receiving, storing and analysing instrumentation is mounted in a snowmobile.

Special attention was given to the emplacement methods and matching of the acceleration transducers. The following conditions guarantee good snow-acceleration measurements:

i. Sensitivity has to be better than $0.01 \mathrm{~m} / \mathrm{s}^{2}$.

ii. Sensitivity has to be constant over a frequency range from 2 to $3 \mathrm{ooo} \mathrm{Hz}$.

iii. The mean transducer density has to be adapted to the snow density $\left(0.1-0.15 \mathrm{Mg} / \mathrm{m}^{3}\right)$.

iv. The transducer dimensions have to be negligible in comparison with the wavelength $\lambda$ of the stress waves.

11 channels (acceleration, pressure, acoustic emission)

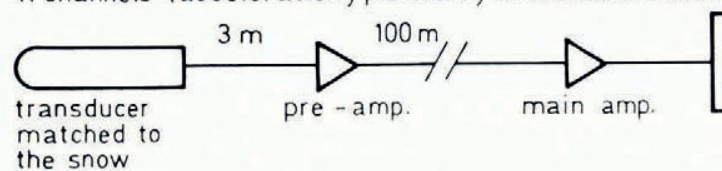

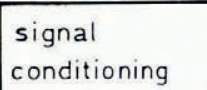

conditioning
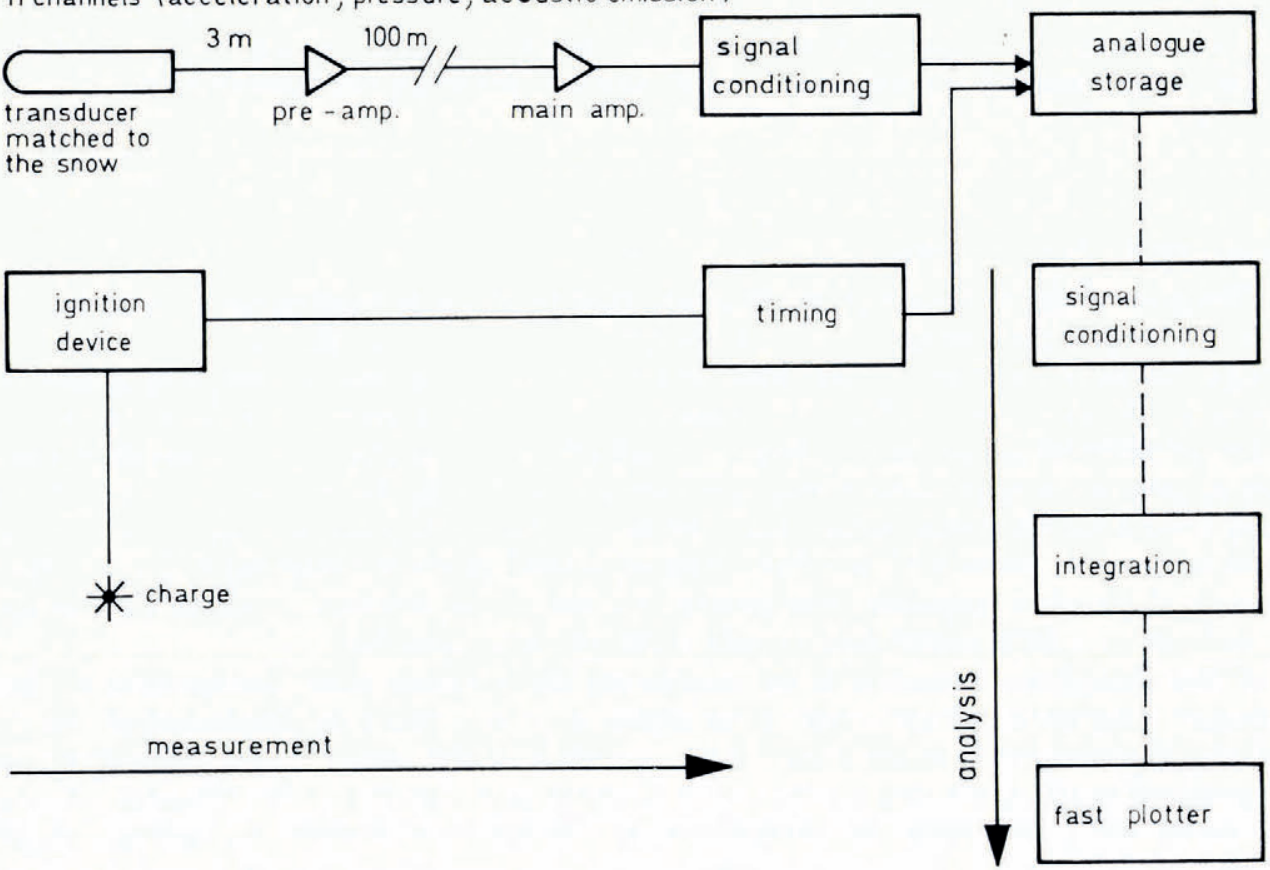

Fig. 2. Main electronic set-up of the experiment.

TABLE I. DESCRIPTION OF THE TRANSDUCERS

\begin{tabular}{|c|c|c|c|c|}
\hline Type & Number & Sensitivity & Frequency range & Construction \\
\hline Acceleration & 6 & $0.01 \mathrm{~m} / \mathrm{s}^{2}$ & $0.002-10 \mathrm{kHz}$ & $\begin{array}{l}\text { Piezoelectric transducer } \\
\text { in foam cylinder } \\
\text { (length }=0.25 \mathrm{~m}, \varnothing= \\
0.05^{2} \mathrm{~m}, \text { mean den- } \\
\text { sity }=0.135 \mathrm{Mg} / \mathrm{m}^{3}\end{array}$ \\
\hline Pressure & 3 & I $\mathrm{Pa}$ & $0.002-3 \mathrm{kHz}$ & Piezuelectric \\
\hline Acoustic emission & I & $10^{-2} \mathrm{~Pa}$ & $100-1000 \mathrm{kHz}$ & Piezoelectric \\
\hline
\end{tabular}

\section{Application}

Measurement of acceleration, velocity, and displacement of the snow

Measurement of structure, void, and air, pressure

Registration of microfractures 
The transducers are embedded in snow holes $(\varnothing=0.052 \mathrm{~m}$, about $3 \mathrm{~m}$ long) which are dug into the snow layers parallel to the snow surface from a pit in the snow cover. This set-up allows one to measure the different parameters such as vertical and radial components of the acceleration, pressures and acoustic emission in the different layers of the snow cover. Seismic measurements are made at the base of each pit. The main experimental lay-out is given in Figure 3 .

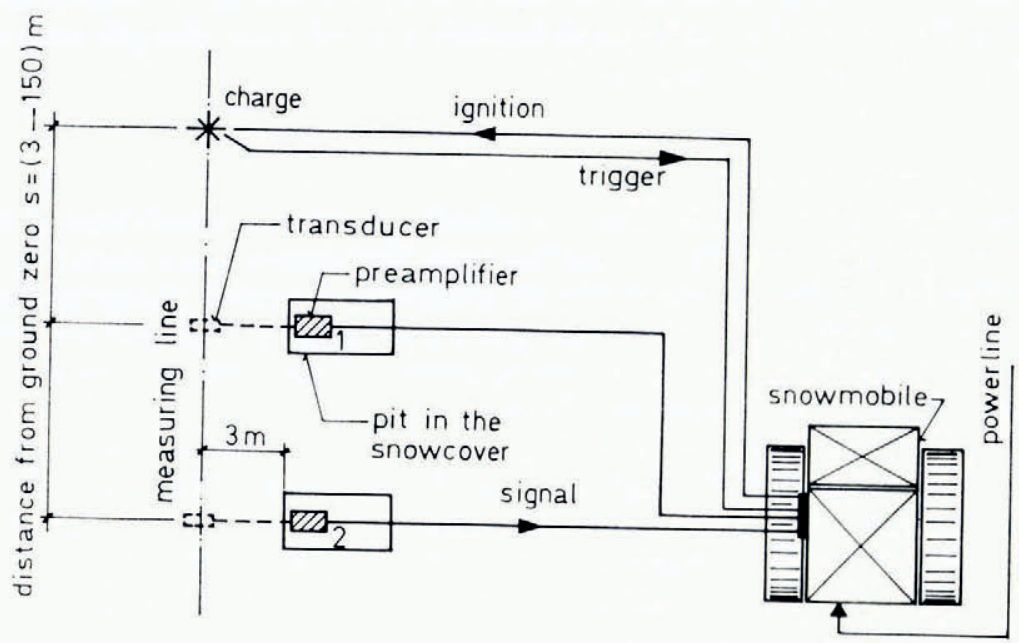

Fig. 3. Main lay-out of the field experiments.

\section{Test SITES}

Preliminary tests were conducted in isothermal spring snow at an altitude of about $2500 \mathrm{~m}$ near the permanent test site of the Eidgenössisches Institut für Schnee- und Lawinenforschung at Weissfluhjoch/Davos. The main tests were carried out during January, February and March 1976 at an altitude of $2000 \mathrm{~m}$ in the area of Parsenn near Davos.

\section{TyPiCAL STRATIFICATION PROFILES AND INSTRUMENTATIONS}

The isothermal wet snow had a mean density of $0.5 \mathrm{Mg} / \mathrm{m}^{3}$, a mean depth of $1.4 \mathrm{~m}$ and a mean Ramm index of $300 \mathrm{~N}$ (Swiss Rammsonde). For the corresponding tests, all shots were ignited below the snow surface; acceleration and pressure measurements were carried out at different depths $d_{\mathrm{A}}$ with radial, azimuthal and vertical sensitive sensors at distances $s$ from ground zero between 3 and $30 \mathrm{~m}$.

The test period of the winter $1975^{-76}$ was characterized by an almost constant snow depth without any heavy snowfalls. The shallow snow depth and the clear weather for long periods resulted in a low mean strength for most test sites. The snow density of the different layers varied from 0.15 to $0.35 \mathrm{Mg} / \mathrm{m}^{3}$. The Ramm index was found to be between ro and $500 \mathrm{~N}$ (only for thin layers), depending on the orientation of the test site. Except for two, all of the ten test sites were flat and almost horizontal. Tests were performed on different types of ground such as hard alpine meadows, swamp and rubble. Acceleration (vertical and radial component), pressure and acoustic emission were measured as a function of depth $d_{\mathrm{A}}$ and distance $s(s=3-150 \mathrm{~m})$. 


\section{SPEGifications OF THE TESTED EXPLOSIVES AND GHARGES}

During the winter of $1975-76$, comparable tests with different explosives, charge sizes, and shapes were performed. The results were normalized to the "normal charge" consisting of I kg "Plastit" (detonation velocity $v_{0}=6900 \mathrm{~m} / \mathrm{s}$, heat of explosion $4.2 \times 10^{6} \mathrm{~J} / \mathrm{kg}$, density $\mathrm{I} .4 \mathrm{Mg} / \mathrm{m}^{3}$ ). The ranges of the specifications of the tested explosives were: detonation velocity $2000-8000 \mathrm{~m} / \mathrm{s}$, heat of explosion $3.2-6 \times 10^{6} \mathrm{~J} / \mathrm{kg}$, density $0.8-1.7 \mathrm{Mg} / \mathrm{m}^{3}$, gas release $0.58-0.97 \mathrm{~m}^{3} / \mathrm{kg}$. The charge mass $W$ was varied from 0.2 to $8 \mathrm{~kg}$. Different arrangements with explosive cords $(0.08 \mathrm{~kg} / \mathrm{m})$ and simultaneously ignited point charges were tested. The shots were fired by electrical detonators.

\section{Evaluation AND discussion of Data}

Propagation time, maximum $\mathrm{N}$-wave amplitude, maximum amplitude of the damped oscillation of the snow cover $\left(b, v_{\mathrm{s}}, x\right)$ and the basic frequencies were determined from the plots given in Figure I. The reproducibility for specific tests without changing the transducer positions was quite high but the data of analogue experiments at different test sites showed a scatter. This scatter resulted from the differing nature of the snow stratification and of the ground, and also from small topographic differences.

The stress wave propagating from the charge attenuates geometrically with the wave amplitude proportional to $s^{-1}-s^{-\frac{1}{2}}$ depending on the geometry. The wave amplitude and frequency also attenuate because they are dependent on the internal-energy dissipation in snow and air and because of coupling losses, for example, between air and snow. For limited ranges of $s$, the effective measured attenuation can be fitted by simple power laws. Some

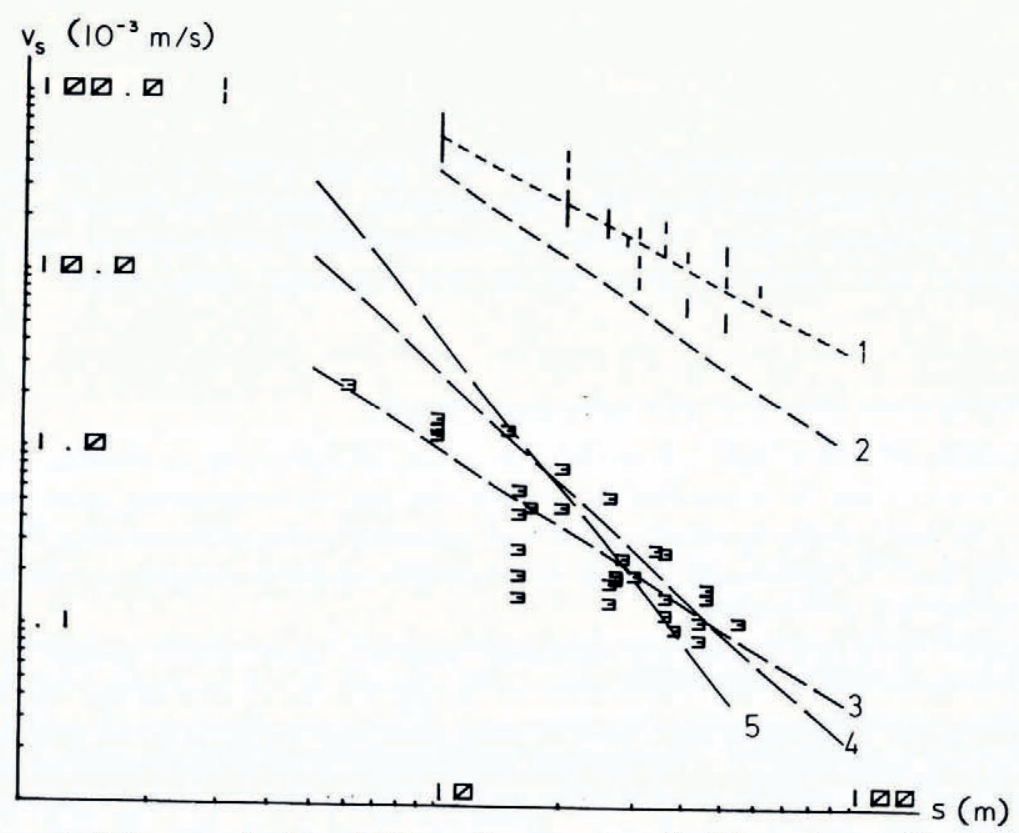

Fig. 4. Displacement velocity $v_{\mathrm{s}}$ as a function of distance $s$ from ground zero for different charge positions $d:(I) I m$ above the snow surface, vertical component for dry snow. (2) I $m$ above the snow surface, radial component for dry snow. (3) at least $0.6 \mathrm{~m}$ below the snow surface, vertical component for dry snow. (4) at least $0.6 \mathrm{~m}$ below the snow surface, radial component for dry snow. (5) at least $0.6 \mathrm{~m}$ below the snow surface, radial component for wet snow.

The measured values are given for curves 1 and 3 . 
Table II. Displacement velocity $v_{\mathrm{S}}$ And N-wave PRessure $p_{\mathrm{N}}$ As A Function of distance $s$ From ground zero FOR A SNOW DEPTH BETWEEN 1.2 AND $1.5 \mathrm{~m}$

Snow cover

Wet snow (spring)

Dry snow (winter)

Position of charge $d$ and transducer $d_{\mathrm{A}}$

$d$ : at least $0.6 \mathrm{~m}$ below snow surface. $d_{\mathrm{A}}$ : at half depth of the snow cover $d$ : I $\mathrm{m}$ above snow surface. $d_{\mathrm{A}}$ : at least $0.8 \mathrm{~m}$ below snow surface

Dry snow (winter)

$d$ : at least $0.6 \mathrm{~m}$ below snow surface. $d_{\mathrm{A}}$ : above centre of snow cover

Dry snow (winter) $d$ : I $\mathrm{m}$ above snow cover. $d_{\mathrm{A}}$ : on snow cover
Power law for the displacement velocity $v_{\mathrm{S}}\left(\mathcal{N}\right.$-wave peak pressure in air $\left.p_{\mathrm{N}}\right)$ as a function of distance $s$

Standard deviation

Radial component:

$v_{\mathrm{rad}}=3.1 \mathrm{~s}^{-2.85} \mathrm{~m} / \mathrm{s}$

Vertical component:

$v_{\text {vert }}=0.945^{-1 \cdot 21} \mathrm{~m} / \mathrm{s}$

Radial component:

$v_{\mathrm{rad}}=1.38 \mathrm{~s}^{-1.57} \mathrm{~m} / \mathrm{s}$

$36 \%$

$29 \%$

$37 \%$

$34 \%$

$v_{\text {vert }}=2.9 \times 10^{-2} \mathrm{~s}^{-1.45} \mathrm{~m} / \mathrm{s}$

Radial component:

$v_{\mathrm{rad}}=0.35^{s^{-2 \cdot 1} \mathrm{~m} / \mathrm{s}}$

$\mathrm{N}$-wave peak pressure in air:

$p_{\mathrm{N}}=5.3 \times 10^{4} s^{-1.12} \mathrm{~Pa}$
I $5 \%$

$7 \%$

of the most important relationships of $p_{\mathrm{N}}(s, d), b(s, d), v_{\mathrm{S}}(s, d)$ and $x(s, d)$ are given in Figure 4 and Table II. The dependence of the displacement velocity $v_{\mathrm{s}}$ as a function of charge depth $d$ for $s>10 \mathrm{~m}$ is given in Figure 5. One readily recognizes that the largest $v_{\mathrm{s}}$ amplitudes resulted from shots on or above the snow surface. The development of the $\mathrm{N}$-wave in air (Fig. 6) showed an almost equivalent dependence on $d$. The dependence of the N-wave peak pressure $p_{\mathrm{N}}$ on snow depth and ground structure is given in Table III.

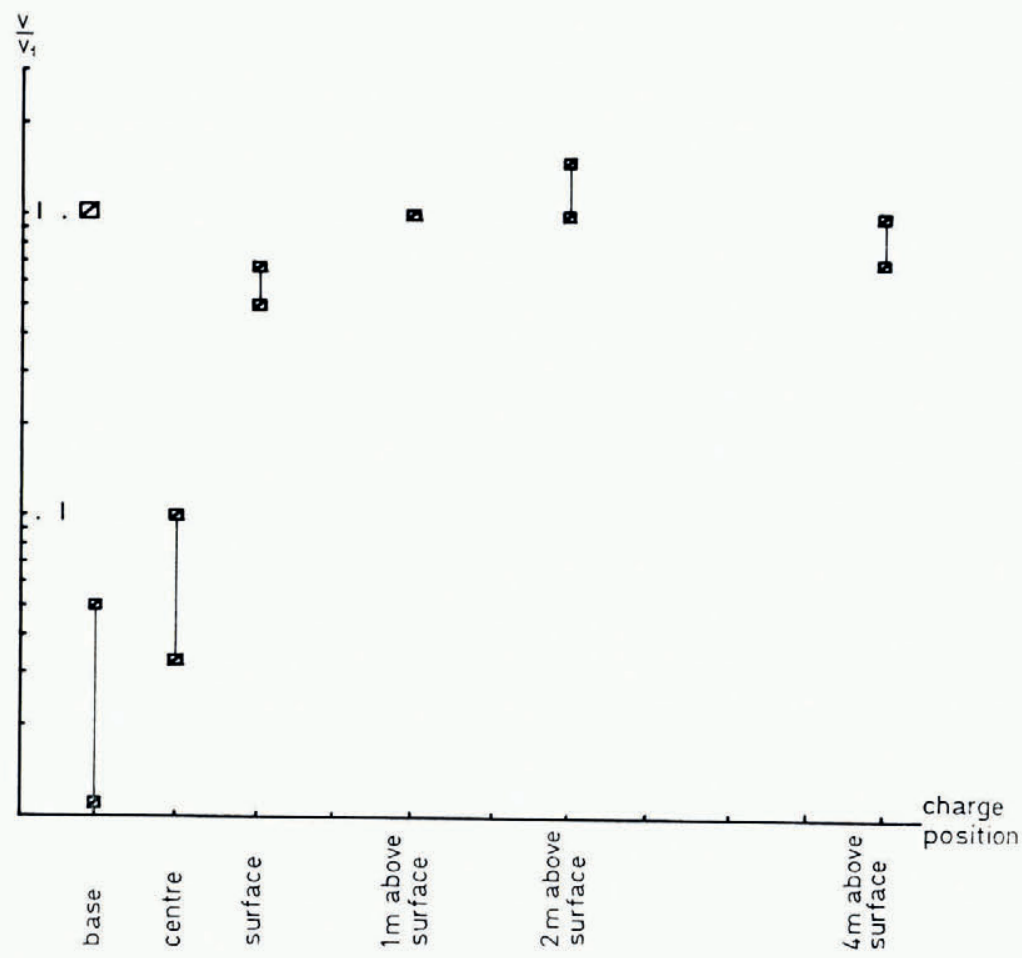

Fig. 5. Ratio of the displacement velocity $v_{\mathrm{s}}$ as a function of charge position to the displacement velocity $v_{1}$ for shots $\mathrm{I} m$ above the snow surface for distances from ground zero $s \geqslant I O m$ and snow depth $h_{\mathrm{S}}=I-2 \mathrm{~m}$ for dry snow. 


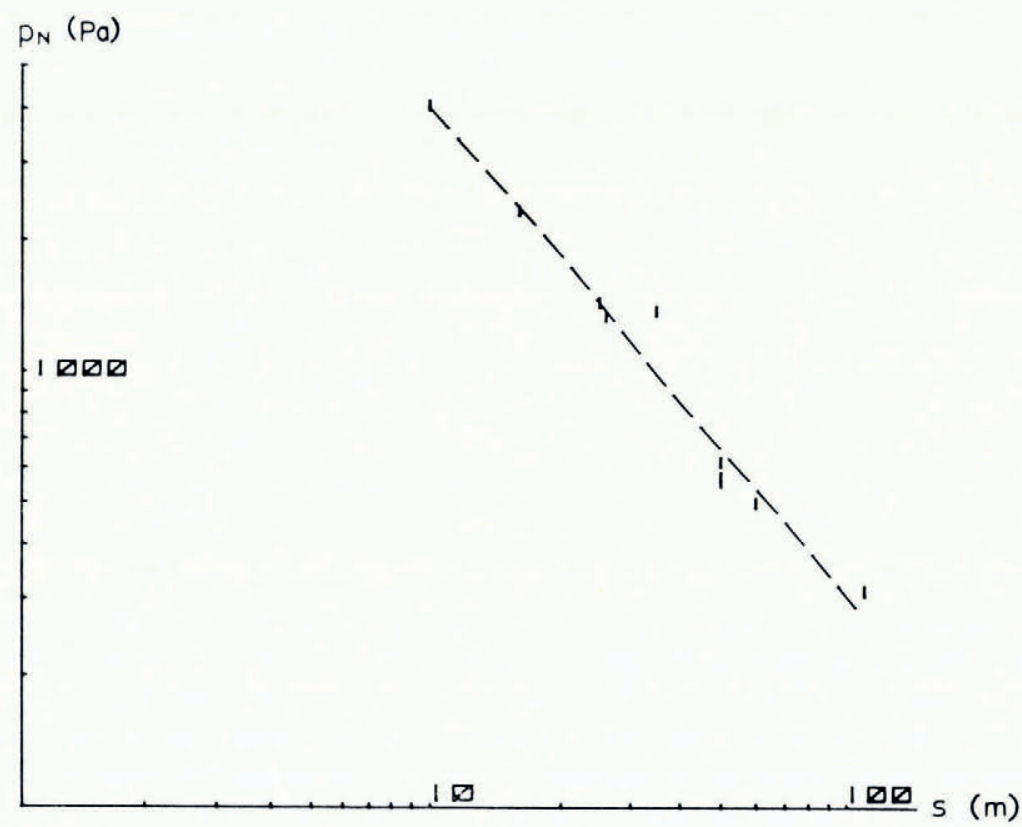

Fig. 6. N-wave peak pressure $p_{\mathrm{N}}$ in air measured on the snow surface as a function of the distance $s$ from ground zero. Charge position I $m$ above the snow surface.

Table III. Attenuation of the N-wave peak pressure in air measured on the snow surface as a FUNCTION OF SNOW DEPTH $h_{\mathrm{s}}$, TYPE OF GROUND AND CHARGE POSITION NORMALIZED TO SHOTS WITH CHARGE POSITION I I ABOVE THE SNOW SURFACE

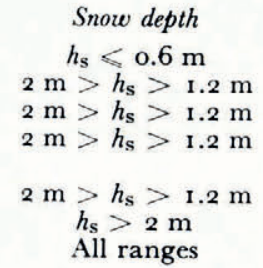

Type of ground

Meadow, rubble

Meadow, rubble

Meadow, rubble

Meadow, rubble

Meadow, rubble

Small bushes on ground
Charge position

Below snow surface

I $\mathrm{m}$ above snow surface

On snow surface

At half depth of the snow cover

Base of snow cover

Below snow cover

Base of snow cover
Ratio $r$ of actual $p_{\mathrm{N}}$ to $p_{\mathrm{N}}$ for detonations $I m$ above surface

$r \geqslant 0.2$

$r=\mathrm{I}$

$r=0.5-0.7$

$r=0.03-0.1$

$r=0.01-0.05$

$r$ decreases with increasing $h_{\mathrm{s}}$ $r$ may decrease further

The dependence of $v_{\mathrm{s}}$ on the charge mass $W$ results in

$v_{\mathrm{s}} \sim W^{0.66-0.69}$ for charges in the snow cover $(d>0)$,

$v_{\mathrm{s}} \sim W^{0.7-0.75}$ for charges on or above the snow surface $\left.(d<0).\right\}$

Taking $v_{\mathrm{s}} \sim W^{\mathfrak{s}}$ independent of $d$, we obtain the reduced distances from ground zero $s_{\text {red }}$ for $W \neq \mathrm{I} k$.

$$
s_{\text {red }}=s_{\text {geom }} W^{\text {ss }} \text {, }
$$

where

$s_{\text {red }}$ is the distance of equal effect for charge weight $W \neq \mathrm{I} \mathrm{kg}$,

$s_{\text {geom }}$ is the geometrical distance from ground zero $(W=\mathrm{I} \mathrm{kg})$,

$\delta=\frac{1}{4}$ for the radial $v$-component in wet snow and charges below the snow surface,

$\delta=\frac{1}{2}$ for the vertical $v$-component in dry snow, independent of $d$. 
The evaluation of the pore-pressure measurements showed that the $\mathrm{N}$-wave penetrates almost unchanged into the snow cover for dry snow. In wet snow with a partly water-filled pore system the $\mathrm{N}$-wave attenuated strongly. The largest measured ratio of maximum to minimum $v_{\mathrm{s}}$ amplitude as a function of the transducer depth $d_{\mathrm{A}}$ was a factor of 2 for dry snow and a factor of 3 for wet snow. The $v_{\mathrm{s}}$ signal amplitude for dry snow seemed to depend mainly on density. Higher density caused larger signals.

For shots above the snow surface, an increase of detonation velocity $v_{0}$ from 2000 to $7000 \mathrm{~m} / \mathrm{s}$ led to a $v_{\mathrm{s}}$ signal increase by a factor of 2 . For shots in the snow cover, a possible $v_{0}$ dependence of the resulting $v_{\mathrm{s}}$ signals was masked by the strong influence of the charge position.

Tests with explosive cords $(0.08 \mathrm{~kg} / \mathrm{m})$ above the snow surface instead of point charges resulted in a $v_{\mathrm{s}}$ signal increase by about $50 \%$ for distances $s>10 \mathrm{~m}$.

From the investigations of the ground dependence of the $v_{\mathrm{s}}$ signal for charges fired anywhere above ground, except for ground covered with small bushes, no significant trend was established. Small bushes may cause a significant attenuation.

The propagation velocities in snow $v_{0 s}$ depended on the amplitude. For wet snow, $v_{0 s}$ changed from $\mathrm{I}$ ooo $\mathrm{m} / \mathrm{s}$ for $s=10 \mathrm{~m}$ to about $750 \mathrm{~m} / \mathrm{s}$ for $s=20 \mathrm{~m}(W=\mathrm{I} \mathrm{kg})$ with a mean of $830 \mathrm{~m} / \mathrm{s}$. For dry snow, the mean value was $820 \mathrm{~m} / \mathrm{s}$ with a weaker $s$ dependence.

The basic frequency of the oscillating snow cover turned out to be independent of snow depth and snow type for the ranges investigated. The basic frequency was $29 \mathrm{~Hz}$ with a standard deviation of $\pm 5 \mathrm{~Hz}$.

Not all problems concerning the acoustic emission measurements can be solved. To increase the sensitivity range, improve the coupling, and reduce the mean density of the transducer system, the piezoelectric transducers were mounted in acoustic wave guides. The main problems arose from oscillations in the transducer system excited by the sharp N-waves. In some cases, emission events could be measured for displacement velocities of $(\mathrm{I}-\mathrm{IO}) \times 1 \mathrm{IO}^{-3} \mathrm{~m} / \mathrm{s}$.

\section{Discussion of the results}

The release of a slab avalanche is initiated by a primary fracture. This primary fracture may occur anywhere in the potential fracture zone (slab bed, line of fracture or Stauchwall). This primary fracture may initiate a fast-propagating (secondary) fracture which cuts the snow cover and releases the slab avalanche. Considering that the strength of snow depends mainly on the strain-rate $\dot{\epsilon}$ (Salm, I97I; Gubler, 1976[a]), it follows that the stability and strength of the snow cover are significantly higher for the primary fracture. The strain-rate $\dot{\epsilon}$ produced by detonation-induced pressure waves is $1 \mathrm{O}^{-4}$ to $\mathrm{IO}^{-3} \mathrm{~s}^{-1}$. The fracture mechanism at this low $\dot{\epsilon}$ is highly dissipative, and the resulting strength is much higher than the brittle strength of snow. From these conditions, we concluded that a secondary fracture may propagate from a fracture volume with a low primary stability even though the stability to primary fracture outside the primary fracture volume is significantly higher.

If, with an artificial pressure wave, the primary fracture volume with the lowest stability should be reached in any case, a method has to be used which exerts a widespread disturbance to the snow cover. From our measurements, it follows that charge ignition above or on the snow surface increases the effective range by $\mathrm{I}-2$ orders of magnitude compared with shots detonated below the snow surface.

To estimate the effective range of a $\mathrm{I} \mathrm{kg}$ normal charge, we began with the following conditions: minimal strength to primary fracture $10^{3}-10^{4} \mathrm{~Pa}$, stability (ratio of strength to stress) I.I, density $\rho=0.1 \mathrm{Mg} / \mathrm{m}^{3}$, velocity of sound $v_{0 \mathrm{~s}}=500 \mathrm{~m} / \mathrm{s}$. From Equation (3) we obtain for the minimal necessary additional amplitude of the displacement velocity $v_{\mathrm{s}}=2 \times\left(1 \mathrm{O}^{-2}-\mathrm{IO}^{-3}\right) \mathrm{m} / \mathrm{s}$. The minimal effective range results in a minimum radius of 17-120 $\mathrm{m}$ for shots above the dry snow cover and of less than $6 \mathrm{~m}$ for shots in the snow cover. 
The corresponding $\mathrm{N}$-wave pressures measured on the snow surface are $p_{\mathrm{N}}=\left(25^{0}-2\right.$ ooo $) \mathrm{Pa}$. The highest measured $\mathrm{N}$-wave pressure caused by sonic booms from aircraft are about roo $\mathrm{Pa}$. For wet snow (10\% water content), a simple estimation of the minimum energy density of a pressure wave to produce one-tenth of the new water surface necessary for fracture of the snow cover shows that fracture initiation with small charges $(W \approx \mathrm{I} \mathrm{kg})$ is only possible in the crater zone. Thus the initiation of a slab avalanche from a gliding wet snow cover is only possible by excavating ditches in pressure zones by the use of explosives.

\section{Conclusions}

I. To release dry slab avalanches on slopes with low stability, the best efficiency results from charges ignited I-2 m above the snow surface, using explosives with high detonation velocities.

2. The effective range for shots above the snow surface is $17-120 \mathrm{~m}$ for $\mathrm{I} k \mathrm{~kg}$ charges, depending on the slope stability.

3. The effective range is proportional to $W^{\frac{1}{2}}$ relative to the range of a $\mathrm{I} \mathrm{kg}$ charge.

4. If the charge cannot be ignited on or above the snow surface (for example projectiles without proximity fuses), a target zone with a shallow snow depth within the necessary effective range has to be chosen. To obtain a comparably effective range, the charge weight has to be increased.

5. For shots on or above the snow surface, simultaneously fired widespread charges have a better effect than a corresponding point charge.

6. From strong sharp bangs resulting from the detonation of charges in the potential fracture zone and resulting flat craters with rounded edges, one can mainly conclude there will be large effective ranges, whereas muffled bangs, large snow fountains, deep craters with angular edges and crater-concentric cracks indicate poor effective ranges.

Further measurements will be undertaken after heavy snowfalls. Laboratory and field experiments still have to be carried out in order to obtain a better correlation between strength, necessary disturbance and acoustic emission. The development of stability in potential fracture zones also has to be studied further.

\section{Acknowledgements}

I am indebted to G. Klausegger, U. Suter and G. Krüsi for preparing the instrumentation and for their assistance during the field tests, and to B. Salm for valuable discussions.

\section{REFERENGES}

Gubler, H. 1976[a]. Künstliche Auslösung von Lawinen durch Sprengungen. Mitteilungen des Eidg. Institutes für Schnee- und Lawinenforschung, No. 32.

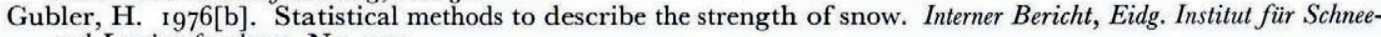
und Lawinenforschung, No. $55^{\circ}$.

LaChapelle, E. R. 1956. Some effects of high explosives on snow: a report on preliminary investigations. U.S. Dept. of Agriculture. Forest Service. Internal Report.

LaChapelle, E. R., and others. 1975. Alternate methods of avalanche control interim report 1974/75, by E. R. LaChapelle, C. B. Brown, R. J. Evans, J. B. Johnson, J. A. Langdon, M. B. Moore, P. L. Taylor. Washington State Highway Dept. Research Program Report I9. I.

Mellor, M. 1973. Controlled release of avalanches by explosives. U.S. Dept. of Agriculture. Forest Service. General Technical Report RM-3, p. 37-49.

Salm, B. 1971. On the rheological behavior of snow under high stresses. Contributions from the Institute of Low Temperature Science, Hokkaido University, Ser. A, No. 23. 


\section{DISGUSSION}

R. List: Would the effectiveness of Dr LaChapelle's gas exploders increase if they were mounted above the snow surface similar to the situation with your explosive charges?

H. Gubler: Conditions of snow stratification are very different between Colorado and the Alps. In many cases exploders have been mounted in positions which favour propagation of pressure waves within the snow-pack and certainly experiments should be tried over the snow surface.

E. R. LaChapelle: Yes. we will try this technique in the near future.

W. ST. LAWRENGE : It would seem more effective to couple the explosive energy into the ground as opposed to the air; can you comment on this please?

GUBLER: We have not performed experiments with charges buried in the ground. Charges positioned on the ground surface result in weak signals in the ground because of bad coupling. In addition, the transmission of seismic signals from the ground to the snow also seems weak. The transmission mechanisms are very different for the ground-snow interface compared with the air-snow interface.

R. L. BRown: How far beyond the crater could you find any sign of plastic deformation?

GUBLER: For a $\mathrm{I}$ kg charge buried in the snow cover, it was about $\mathrm{I}-1.5 \mathrm{~m}$ with respect to the crater central axis.

St. Lawrence: How did you determine the zone of plastic deformation?

Gubler: By measuring the deformation of vertical coloured columns in the snow cover.

M. Mellor: Do you have any problems with impedance matching between transducers and the snow?

GUBLER: We usually require that transducers have similar density to the snow and possess negligible dimensions so that they move more or less as the snow moves.

M. DE Quervain: The higher efficiency of charges applied by cableways (above the snow cover) against conventional shooting is not questioned. I only wish to mention that "successful" or "unsuccessful" shooting may depend upon human decisions. A very cautious shooting crew operating in unfavourable conditions will get a much lower score of "successes" (i.e. avalanche releases) than a crew taking more risks.

Gubler: Very cautious shooting will even be favoured by the use of cableways because of the lower costs per charge. 